\title{
SELECTAREA GENOTIPURILOR REZISTENTE LA TEMPERATURI ÎNALTE ȘI DEFICITUL HIDRIC DUPĂ VARIABILITATEA POLENULUI
}

\author{
Antoci Liudmila \\ Institutul de Genetică, Fiziologie și Protecție a Plantelor, Chișinău, Republica Moldova \\ e-mail: antlud58@mail.ru
}

\begin{abstract}
Problemele, care stau în faţa savanților nu sunt lipsite de necesitatea creării genotipurilor cu o productivitate și rezistență înaltă la factorii stresanți ai mediului (temperatură înaltă, limită de umiditate). Procesul de selectare a formelor rezistente presupune utilizarea metodelor tradiționale clasice, cât și celor mai performante tehnologii. Acțiunea factorilor nefavorabili poate fi diminuată prin ameliorarea genotipurilor rezistente. După părerea marelui savant N.I.Vavilov mediul este un bun și puternic factor pentru ameliorare.
\end{abstract}

Reeșind din cele menționate, cercetările au fost axate pe evaluarea și selectarea genotipurilor rezistente la temperaturile înalte și deficitul hidric. Au fost incluse în studiu 8 combinații hidride în generația $\mathrm{F}_{3}$ de tomate, plantele au fost cultivate pe câmpul experimental al IGFPP. La etapa de înflorire s-a colectat polenul genotipurilor, care ulterior, a fost supus tratării termice în termostat cu regimul de temperatură de $40^{\circ} \mathrm{C}$ timp de 2 și 4 ore, după ce a urmat cultivarea polenului fiecărui genotip variantele martor și probă pe mediu nutritiv artificial. După 3 ore de cultivare, la microscop au fost analizate preparatele și s-au stabilit următoarele caractere: viabilitatea și rezistența polenului, lungimea tuburilor polinice și rezistența acestora. Evaluarea după rezistență la deficitul hidric s-a efectuat prin utilizarea mediului cu sorbit de $85 \%$ - varianta probă, ca martor a servit polenul uscat. Analiza efectuată la microscop a stabilit, că fondalul de temperatură înaltă a modificat în mod diferit valorile caracterelor polenului genotipurilor analizate. După așa indicatori ca viabilitatea polenului și lungimea tuburilor polinice în varianta probă valorile polenului au diminuat de $1,04-8,0$ ori în comparație cu martorul și în dependență de genotip. Această variație a fost determinată veridic de factorul termic, genotip și interacțiunea lor. Este necesar de remarcat, că la peste $40 \%$ de genotipuri, în rezultatul acțiunii termice, viabilitatea polenului s-a micșorat de 5 ori, dar au fost evidențiate trei genotipuri, care au atestat o rezistență înaltă a polenului la temperatură înaltă de la 69 până la 94\%. Analiza tuburilor polinice a demonstrat o rezistență înaltă de $70-92 \%$ la $90 \%$ de populaţii hibride studiate. Prelucrarea statistică prin metoda dispersională polifactorială a permis stabilirea cotelor de influență în variabilitatea caracterelor gametofitului masculin. Astfel, variabilitatea viabilităţii polenului este determinateă în mare parte de acțiunea factorului termic, ce constitue $90 \%$, pe când acțiunea genotipului și interacțiunea ambilor factori a fost egală cu 5\%. Stresul termic a avut o acțiune și asupra lungimii tuburilor polinice, cu valoarea de $77 \%$, însă influența genotipului a fost de 5 ori mai mică. În scopul testării genotipurilor rezistente la acțiunea deficitului de umiditate a fost evaluat polenul pe mediu cu sorbit. S-a stabilit, că insuficiența de umiditate a contribuit la modificarea mărimii grăuncioarelor de polen în direcția micșorării de 1,9- 3,0 ori în dependență de genotip. Combinațiile hibride Mary Gratefully x Tomiș; Mary Gratefully x Prestij; Mary Gratefully x Mihaela; Veneț x Mihaela au fost evidențiate cu o rezistență înaltă cuprinsă între $75-79 \%$. Analiza statistică a permis stabilirea contribuției fiecărui factor în variabilitatea viabilității și rezistenței polenului. Astfel, factorul termic a avut o pondere mai înaltă, ce a constituit 89 - 92\%, pe când acțiunea genotipului a fost de numai 5-7\%. Este necesar de menționat, că au fost obținute rezultate importante privitor la termorezistența polenului în decurs de doi ani consecutivi, care ne-au permis să evidențiem trei combinații hibride cu rezistență înaltă: Veneț x Mihaela;Veneț x Elvira; Victorina x Mihaela.

Rezultatele obținute denotă despre posibilitatea selectării genotipurilor rezistente la factorii nocivi ai mediului ambiant, nu doar folosind metodele clasice tradiționale, ci și celor noi prin ameliorarea la nivel de gametofit masculin, utilizând metode simple, veridice și eficiente. 